Gazi University
Journal of Science
http://dergipark.gov.tr/gujs

\title{
Scheduling and Rostering of Temporary Staff to Deal with Periodically Increasing Demand in Retail Sector: An Application
}

\author{
Ahmet CUREBAL ${ }^{1}$ (D), Serkan KOCTEPE ${ }^{1}$ (D) Tamer EREN $^{1, *}$ (D), Emir Huseyin OZDER ${ }^{2}$ \\ ${ }^{1}$ Kirlkkale University, Department of Industrial Engineering, 71450, Kirlkkale, Turkey \\ ${ }^{2}$ Alanya Alaaddin Keykubat University, Department of Industrial Engineering, 07425, Antalya, Turkey
}

\section{Highlights}

- This paper focuses on meeting periodically increasing demand by scheduling employed staff.

- 0-1 integer programming is used to establish mathematical model.

- The competence and qualification of the staff are taken into consideration.

\begin{tabular}{l} 
Article Info \\
\hline \\
Received: 30 Jan 2021 \\
Accepted: 07 Sep 2021 \\
Keywords \\
\hline Staff scheduling \\
Rostering \\
O-1 Integer programming \\
Increasing demand \\
Staff competency
\end{tabular}

\begin{abstract}
Temporary employment is a need to meet periodically increasing demand. It is arranged for a limited number of days and its service quality output is observed instantly. These make the planning phase complicated. In the process, the priority of businesses is to meet the increasing demand and to regulate the workload according to the terms of the period. Solving the periodic increase in demand by providing permanent employment can cause businesses to face the costs arising from excess employment in the long term. Generally, businesses manage these periods by hiring new staff. The most critical problems of the process are the suitability of the temporarily employed staff to work and whether they are suitable for the competencies in the job description. It is expected to achieve an efficiency equivalent to the cost to be incurred for this need that occurs in certain time periods. Adaptation processes, the effects of today's pandemic virus, and ergonomics issues owing to some tasks are the other basic constraints of this planning process. In this study, the problem of scheduling and rostering of staff requested for the problem of staff shortage owing to periodically increased demand has been solved. 50 candidate staff were evaluated in 4 competency types. Thus, an optimized service quality and staff costs has been achieved for this periodic staff need. For problem solving, 0-1 integer programming model was established and the proposed model, is written in ILOG CPLEX Studio IDE and is solved with the CPLEX solvent.
\end{abstract}

\section{INTRODUCTION}

Today, companies employ temporary employees to meet the periodically changing demand. Particularly, in the retail sector, demands change on a periodic basis. Businesses need a new work plan in order to adapt to this changing demand environment and to balance the workload of staff. In these processes, additional staff are needed. It is very important in terms of service quality that the staff who will work in a certain time period adapt to the task and other employees [1]. It is expected that the efficiency to be achieved from the staff in these processes will be satisfactory, since the temporary staff costs are well above the permanent staff costs due to the outsourcing.

Today, although the ability of businesses to continue their activities depends on many factors, one of the most important issues among these is staff scheduling and rostering problems. Staff scheduling and rostering problems are one of the most basic types of problems for businesses in production systems, service systems or mixed systems. Many different solution approaches to staff scheduling and rostering problems 
have been used in the literature. Depending on the capacity of the data and the conditions problem has, optimal methods or heuristics can be used.

The main purpose focused on staff scheduling and rostering problems is to make fair decisions while meeting the demand, to use the workforce effectively, to assign the staff to the appropriate positions, and to prepare a suitable working environment for both the businesses and their staff. Staff costs have the largest share among operating expenses. The efficiency of the staff directly affects the quality of the work. In today's competitive environment, businesses must ensure that their staff cab work efficiently and effectively. This is achieved through a fair schedule and assignment planning.

There have been many studies on staff scheduling in the literature. Many different solution approaches have been used to this type of problem. In this study, 0-1 integer programming method, one of the operations research methods, was used for problem solving. The paper is shaped as follows: After a brief introduction, the next section gives an information on temporary staff scheduling and rostering, after that literature overview around the problems of staff scheduling and rostering is presented. The next section covers an application which shows a solution approach to deal with the problem. The last section gives related discussions and the conclusion of the study.

\section{TEMPORARY STAFFING}

In the globalizing world, businesses compete with their international rivals. Businesses have many stages to improve, personnel management is one of the most important of them. Practically in sectors where demands change periodically, businesses should work more on staff management. A business that employs temporary staff must ensure that its temporary staff is competent and compliant with the working system. In this challenging process, businesses prefer to work with companies that supply staff for various purposes. Thus, businesses can hire experienced staff in their work areas. Some staff employed periodically, and their areas of competence are shown in Table 1.

Table 1. Areas and staff types demanded for that area

\begin{tabular}{|l|l|}
\hline \multicolumn{1}{|c|}{ Area } & \multicolumn{1}{c|}{ Staff Types } \\
\hline Seminar Organization & Stage technical team, team in charge of the halls, hall general manager. \\
\hline Fair Organization & $\begin{array}{l}\text { Stage technical team, booth technical team, in-hall attendant team, booth } \\
\text { attendant team, unit officers, general team supervisor. }\end{array}$ \\
\hline Congress Organization & $\begin{array}{l}\text { Stage technical team, reception team, transfer team, hall teams, Team } \\
\text { supervisors, Registration team, organization official for required contact } \\
\text { and flow control. }\end{array}$ \\
\hline Launch Events & $\begin{array}{l}\text { Technical installation team, Merchandiser (sales support staff), stand team, } \\
\text { stand responsible. }\end{array}$ \\
\hline $\begin{array}{l}\text { Promotion } \\
\text { Advertising Organization }\end{array}$ & $\begin{array}{l}\text { Technical installation team, Merchandiser (sales support staff), stand team, } \\
\text { stand responsible. }\end{array}$ \\
\hline Concert Events & $\begin{array}{l}\text { Technical installation team, ticket sales team, ticket control team, guidance } \\
\text { team, team managers, general team manager. }\end{array}$ \\
\hline $\begin{array}{l}\text { Entertainment } \\
\text { Organizations }\end{array}$ & $\begin{array}{l}\text { Costumed or freely dressed entertainment team, DJ, animator, guidance } \\
\text { team, team managers, general team manager. }\end{array}$ \\
\hline Exhibition Events & Technical installation team, booth team, booth manager. \\
\hline Retail Support Events & Marketing, Merchandiser (sales support staff), Supervisor. \\
\hline
\end{tabular}

Firms that provide additional personnel services also serve the retail sector, which requests personnel to meet their periodically changing demands. Firms that provide additional staff services also serve the retail sector, which requests staff to meet their periodically changing demands. Firms in the retailing industry hire temporary staff to provide quality service in changing demand environments. The jobs of temporary staff to be employed in this sector and the definitions of these jobs are shown in Table 2. 
Table 2. Jobs in retail sector and their definitions

\begin{tabular}{|l|l|}
\hline \multicolumn{1}{|c|}{ Jobs } & \multicolumn{1}{c|}{ Job Definitions } \\
\hline Marketing & $\begin{array}{l}\text { Checking the products in stock, encouraging the store to sell its own products, } \\
\text { controlling Merchandiser staff. }\end{array}$ \\
\hline $\begin{array}{l}\text { Merchandiser } \\
\text { (Male) }\end{array}$ & $\begin{array}{l}\text { Following the distribution of the products, ensuring that the products on the shelves } \\
\text { attract attention, controlling and renewing the products on the shelves. }\end{array}$ \\
\hline $\begin{array}{l}\text { Merchandiser } \\
\text { (Female) }\end{array}$ & Keeping in close contact with the customer to advertise the products. \\
\hline Supervisor & $\begin{array}{l}\text { Controlling the marketing and Merchandiser teams, making sure that employees } \\
\text { take precautions against the pandemic virus and that they are working in accordance } \\
\text { with occupational health and safety. }\end{array}$ \\
\hline
\end{tabular}

\section{RELATED WORKS}

Asensio-Cuesta et al. [2] proposed a new scheduling model based on staff productivity and ergonomic conditions. They used genetic algorithm, one of the heuristic methods, as the solution method. Todovic et al. [3] addressed the problem of scheduling civil servants in their work. They used goal programming as a solution method. Ünal and Eren [4] examined the issue of scheduling in the service sector in a government agency. They proposed a solution with the weighted goal programming method. Ciritcioğlu et al. [5] discussed the problem of scheduling security guards in this study. As the application point, they aimed to find a balanced solution in the assignment of the staff at Kirıkkale University to the shifts. As a solution method, they used the goal programming method, one of the operations research subjects. Varl1 and Eren [6] discussed the shift scheduling problem of nurses working in the operating room, intensive care and emergency departments in a hospital in Kirıkkale. They proposed a model for problem solving with goal programming method. Varlı et al. [7] discussed the problem of nurse scheduling in their study. They have developed a mathematical model that takes into account the nurses' special situation constraints. They proposed a monthly schedule using the goal program method. Özder et al. [8] discussed the problem of scheduling for cleaning personnel in the service sector. They proposed a solution using goal programming method. Bedir et al. [9] addressed the problem of personnel scheduling, taking into account ergonomic working conditions in their studies. They used analytic hierarchy process (AHP) and goal programming methods in the study. Özcan et al. [10] In their work, the personnel employed in hydroelectric power plants applied the scheduling problem. They used goal programming, one of the operations research topics, as a solution method for the shift scheduling problem. Taş et al. [11] discussed the problem of monorail project selection in their studies. Alternative projects for the monorail line to be established have been evaluated in the light of the determined criteria and aimed to select the most suitable project. Solution methods are AHP and Goal programming methods. Gür et al. [12], in their work, they focused on the selection of monorail projects in Ankara. By using AHP and 0-1 Goal Programming methods, they have proposed a solution for the selection of transportation projects to the routes determined in Ankara Metropolitan Municipality. Varl1 et al. [13] dealt with the problem of scheduling an exam program in a university. They used goal programming method as the solution method of the problem. De Bruecker et al. [14] discussed the problem of scheduling for personnel involved in aircraft maintenance in their work. They proposed a solution model with mixed integer programming method, taking into account the skill criteria. Koçtepe et al. [15] dealt with the problem of scheduling part-time personnel in the organization sector. In order to maximize the competencies of the personnel, they created a mathematical and solved the model with $0-1$ integer programming. Yelek et al. [16] The problem of determining the shift order of forty part-time students working in the Central Library of Kurıkkale University in a one-month period was discussed. The model was created by taking into account the special demands of the part time personnel. Goal programming method was used to solve the problem. Koçtepe et al. [17] have addressed the problem of scheduling personnel assigned to basketball matches in the organization sector. They developed a mathematical model aiming at cost minimization, taking into account the personnel competency scores. They used the 0-1 integer program method as their solution method. Danışan et al. [18] examined 1330 electrical equipment in a large-scale hydroelectric power plant and determined the criticality levels for the plant. AHP, technique for order preference by similarity to ideal solutions (TOPSIS) and integer 
Programming methods are used. At the end of the study, 7 main electrical equipment groups, critical to which the periodic maintenance strategy can be applied, were determined and made an application. Cürebal et al. [19] addressed the personnel scheduling problem of an organization firm in their work. They developed a mathematical model that takes the costs of the personnel and the positions they can be assigned as criteria. They used promethee from multiple criteria decisions making methods and goal programming from operations research models as their solution method. Cürebal et al. [20] dealt with the problem of scheduling staff members for a promotional organization. They aimed to maximize the competence of the personnel and to minimize the costs. They used AHP and Goal programming as their solution method. Heimerl and Kolisch [21] find out the problem of simultaneously scheduling IT-projects and assigning multi-skilled internal and external human resources by modelling the problem using mixed-integer linear program with tight LP-bound. Their objective is to minimize labor cost. Bender et al. [22] solve a problem of scheduling of customer visits to multi-period service territory. In this problem, presenting an exact branch-and-price algorithm and use real-world data sets. The main purpose of the study is to demonstrate the curative effect of fair, balanced and competency-based personnel scheduling including ergonomics issues.

\section{CASE STUDY}

The application covers the selection, assignment, and scheduling of the staff to meet the additional personnel demand of a company. The problem was solved upon the need for additional staff to work in 4 different positions for a period of 31 days. In the study, 50 personnel were evaluated. Tasks where personnel are required are supervisor, marketing, and merchandiser. Staff members have 4 types of competence points. In addition to the competency scores, 3 personnel data are also taken into account in the model. The working times of the tasks are also different, while the merchandiser task demands additional staff in the last 11 days of the planning period, while the other tasks request staff every weekday during December. The application flow chart is shown in Figure 1. According to the flowchart in Figure 1, after the problem is determined, a score is determined with the relevant data of the personnel under 3 separate headings, and a 0-1 Integer mathematical model is established accordingly. Subsequently, personnel assignment is made based on the results of this model.

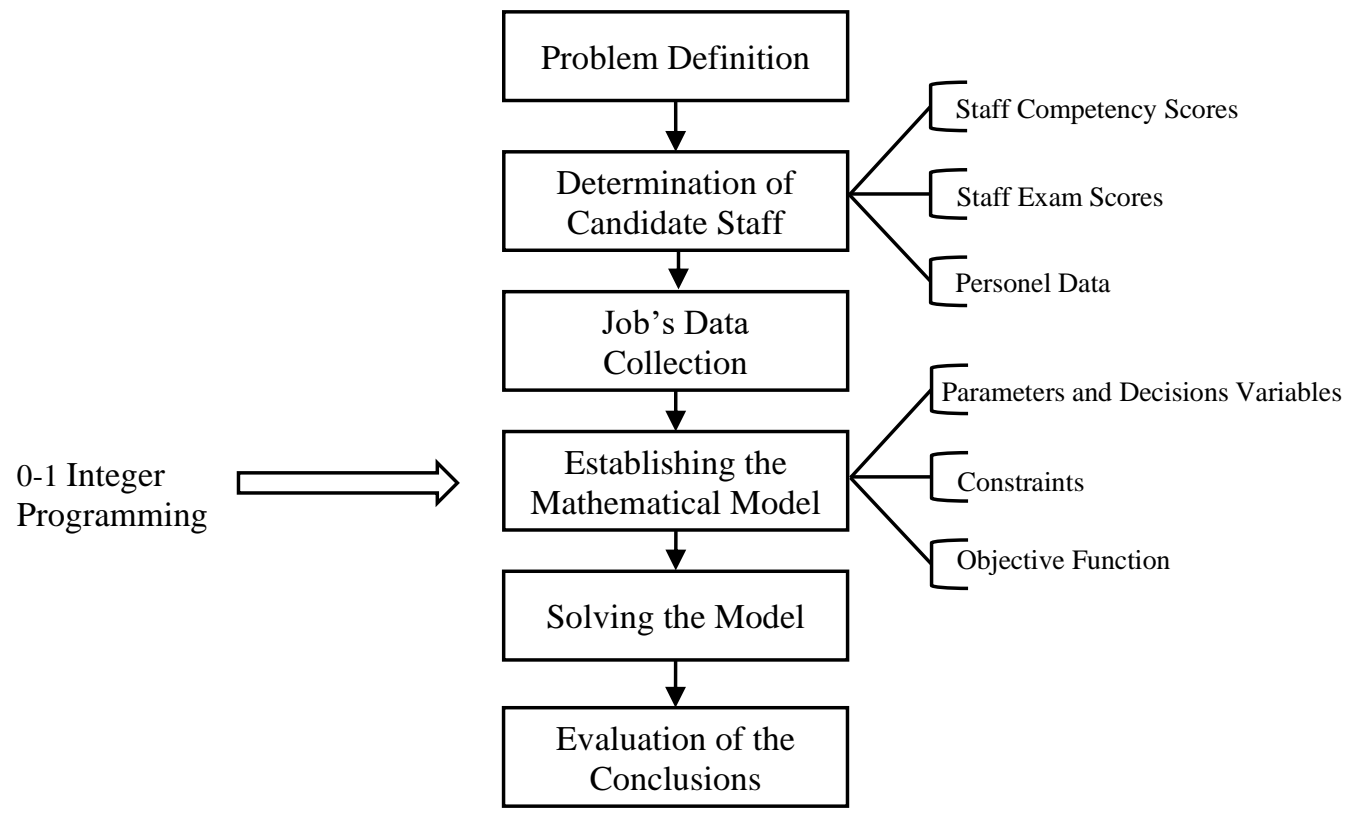

Figure 1. Application flow chart

\subsection{Problem Definition}

A company operating in the food sector in Ankara demands additional staff to work for a period of 31 days for some of their duties. Different competencies and qualification are expected from the staff for each task. The implementation is on how many staff the organization will need and the assignment and scheduling of 
the staff to the tasks. The number of staff to be elected is 50 people. 4 competence and 3 trait data of the said 50 people were also taken into account in the application. In addition, the model is also taken into consideration not to select the personnel with chronic diseases as the pandemic virus precaution. Within the scope of the data generated from the previous studies of the staff, there are competency scores on each task. In addition, a test covering their jobs was applied to the staff and the score data they achieved from it were also included in the model. Each task requires different minimum score and various qualifications. The model aims to maximize the competency score total of the assigned staff.

Supervisor and Marketing jobs of the assignment demands additional staff every weekday for 31 days. Merchandiser task is divided into 2 sub-jobs in which men and women will be assigned, and it demands personnel from the 21 st to the last day of the month. Within the scope of the application, a model was established to take into account the demands of the jobs as well as maximizing the competencies of the personnel to be appointed.

\subsection{Data}

The jobs and their information that the company to which the study is applied needs additional staff to meet the increasing demand are shown in Table 3. Unlike Table 2, in the Table 3, information is given considering the job information of the company and its similar points with Jobs in retail sector.

Table 3. Jobs Information

\begin{tabular}{|c|c|c|c|}
\hline Jobs & Definitions & $\begin{array}{c}\text { The Number } \\
\text { of Staff } \\
\text { Demanded }\end{array}$ & $\begin{array}{l}\text { Days when jobs } \\
\text { demand staff }\end{array}$ \\
\hline Marketing (M) & $\begin{array}{l}\text { To take orders of the stores, to control } \\
\text { the products in stock, to encourage the } \\
\text { store to sell its own products, and to } \\
\text { control the personnel in the } \\
\text { Merchandiser job. }\end{array}$ & 12 & $\begin{array}{c}01.12 .20-31.12 .20 \\
\text { (31 days) }\end{array}$ \\
\hline $\begin{array}{l}\text { Merchandiser } \\
\text { (Me) }\end{array}$ & $\begin{array}{l}\text { It has two separate sub-jobs; } \\
\text { MMerchandiser (Mm) where men will } \\
\text { work and FMerchandiser (Fm) where } \\
\text { women will work. Duties: To follow the } \\
\text { distribution of the brand's existing } \\
\text { products on the shelves in the store, to } \\
\text { carry out activities that will make the } \\
\text { products stand out on the shelves, to } \\
\text { identify the missing products on the } \\
\text { shelves, to place these products on the } \\
\text { shelves, and to direct the target portfolio } \\
\text { to the products of the brand in the store. }\end{array}$ & 12 & $\begin{array}{c}21.01 .20-31.12 .20 \\
(11 \text { days })\end{array}$ \\
\hline Supervisor (S) & $\begin{array}{l}\text { Controlling the marketing and } \\
\text { Merchandiser teams, making sure that } \\
\text { employees take precautions against the } \\
\text { pandemic virus and that they are } \\
\text { working in accordance with } \\
\text { occupational health and safety. }\end{array}$ & 1 & $\begin{array}{c}01.12 .20-31.12 .20 \\
\text { (31 days) }\end{array}$ \\
\hline
\end{tabular}

Competence and trait data of 50 staff were used in the study. Staff are scored for each task on a scale of 110, based on information from their past work. In addition, a test was applied to the staff regarding their jobs and they were evaluated on a scale of 1-100 (ES) at the end of the test. The competency data used for each staff (S.No) are shown in Table 4. In Table 4, an evaluation score between 0-100 was obtained for each personnel. These scores are given under the heading ES. 
Table 4. Staff competency scores

\begin{tabular}{|c|c|c|c|c|c|c|c|c|c|c|c|c|c|c|c|c|c|}
\hline No. & $\mathbf{S} \mathbf{M}$ & Me & ES & S.No & $\mathbf{S}$ & $1 \mathbb{1}$ & Iel & & S.No. & $S \mathbb{I}$ & $\mathbf{I} \|$ & 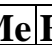 & & S.No & $\mathbf{S} \mid \boldsymbol{\Lambda}$ & $\mathbf{M} \mathbf{M}$ & \begin{tabular}{|l|l|}
$\mathbf{e}$ & $\mathbf{E S}$ \\
\end{tabular} \\
\hline 1 & 56 & 8 & 70 & 14 & 9 & & 8 & 85 & 27 & 5 & & 87 & 70 & 39 & 45 & 99 & 60 \\
\hline 2 & \begin{tabular}{|l|l|}
6 & 8 \\
\end{tabular} & 9 & 65 & 15 & 7 & & 9 & 85 & 28 & 6 & & & 75 & 40 & 477 & \begin{tabular}{l|l|}
7 & 7 \\
\end{tabular} & \\
\hline 3 & \begin{tabular}{|l|l|}
7 & 9 \\
\end{tabular} & 9 & 80 & 16 & 8 & & 8 & 65 & 29 & 5 & & 9 & 70 & 41 & $\begin{array}{ll}6 & 7\end{array}$ & 7 & 75 \\
\hline 4 & \begin{tabular}{l|l}
8 & 6 \\
\end{tabular} & 8 & 90 & 17 & 7 & & 8 & 85 & 30 & 4 & & 7 & 85 & 42 & 7 & 7 & \\
\hline 5 & \begin{tabular}{|l|l}
9 & 7 \\
\end{tabular} & 7 & 95 & 18 & 8 & & & 90 & 31 & 4 & & 7 & 90 & 43 & \begin{tabular}{|l|l|}
5 & 8 \\
\end{tabular} & 8 & 90 \\
\hline 6 & \begin{tabular}{|l|l|}
8 & 7 \\
\end{tabular} & 8 & 80 & 19 & 4 & & & 65 & 32 & 5 & & 8 & 85 & 44 & 45 & 9 & 85 \\
\hline 7 & \begin{tabular}{|l|l|}
7 & 8 \\
\end{tabular} & 8 & 85 & 20 & 5 & & 6 & 95 & 33 & 6 & & 8 & 80 & 45 & \begin{tabular}{l|l}
6 & 7 \\
\end{tabular} & 7 & 80 \\
\hline 8 & \begin{tabular}{l|l}
8 & 6 \\
\end{tabular} & 9 & 75 & 21 & 3 & & 8 & 85 & 34 & 46 & & 9 & 75 & 46 & \begin{tabular}{|l|l|}
4 & 8 \\
\end{tabular} & 8 & 85 \\
\hline 9 & \begin{tabular}{|l|l|l|}
7 & 8 \\
\end{tabular} & 7 & 80 & 22 & 7 & & & 95 & 35 & 5 & & 9 & 60 & 47 & 45 & 9 & 80 \\
\hline 10 & \begin{tabular}{|l|l|}
8 & 9 \\
\end{tabular} & 8 & 90 & 23 & 5 & & 7 & 85 & 36 & 4 & & 7 & 85 & 48 & $\begin{array}{lll}5 & \\
\end{array}$ & 9 & 60 \\
\hline 11 & \begin{tabular}{|l|l|}
9 & 8 \\
\end{tabular} & 9 & 100 & 24 & 4 & & 7 & 80 & 37 & 5 & & 7 & 90 & 49 & \begin{tabular}{|l|l|}
4 & 8 \\
\end{tabular} & 7 & 90 \\
\hline 12 & \begin{tabular}{|l|l|}
7 & 9 \\
\end{tabular} & 8 & 90 & 25 & 6 & & & 70 & 38 & & & & & 50 & & & 70 \\
\hline 13 & \begin{tabular}{|l|l|}
8 & 9 \\
\end{tabular} & & & 26 & & & & & & & & & & & & & \\
\hline
\end{tabular}

In addition to the competency scores, some data belonging to the staff were also used in the model because the tasks demand various conditions. Data used; gender (G), having / not having a driver's license (D) and chronic disease (C) status within the scope of precaution to the pandemic virus. These data belonging to the personnel are shown in Table 5. Some letters are used in Table 5. Their meaning is as follows: The first column indicates the personnel number. It means Y: Yes, N: No, M: Male, F: Female. The letter D indicates the driver's license status. If he has a license, he is assigned the letter $\mathrm{Y}$, if not, the letter $\mathrm{N}$. The letter $\mathrm{G}$ indicates the gender of the personnel. It gets the letter $\mathrm{F}$ if it's a woman and an $\mathrm{M}$ if it's a man.

Table 5. Staff trait data

\begin{tabular}{|c|c|c|c|c|c|c|c|c|c|c|c|c|c|c|c|}
\hline S.No. & D & $\mathbf{G}$ & C & S.No. & D & $\mathbf{G}$ & C & S.No. & D & G & C & S.No. & D & $\mathbf{G}$ & $\mathrm{C}$ \\
\hline 1 & $\mathrm{Y}$ & $\mathrm{F}$ & $\mathrm{N}$ & 14 & $\mathrm{Y}$ & $F$ & $\mathrm{~N}$ & \begin{tabular}{|l|}
27 \\
\end{tabular} & $\mathrm{Y}$ & M & $\mathrm{N}$ & 39 & $\mathrm{~N}$ & $\mathrm{M}$ & $\mathrm{N}$ \\
\hline 2 & $\mathrm{Y}$ & $\mathrm{F}$ & $\mathrm{N}$ & 15 & $\mathrm{Y}$ & $\mathrm{F}$ & $\mathrm{N}$ & 28 & $Y$ & M & $\mathrm{N}$ & 40 & $\mathrm{Y}$ & $\mathrm{M}$ & $\mathrm{N}$ \\
\hline 3 & $Y$ & $\mathrm{~F}$ & $\mathrm{~N}$ & 16 & $\mathrm{Y}$ & M & $\mathrm{N}$ & 29 & $Y$ & M & $\mathrm{N}$ & 41 & $\mathrm{Y}$ & M & $\mathrm{N}$ \\
\hline 4 & $Y$ & $\mathrm{~F}$ & $\mathrm{~N}$ & 17 & $Y$ & $M$ & $\mathrm{~N}$ & 30 & $\mathrm{~N}$ & M & $\mathrm{N}$ & 42 & $Y$ & $M$ & $\mathrm{~N}$ \\
\hline 5 & $\mathrm{Y}$ & $\mathrm{F}$ & $\mathrm{N}$ & 18 & $\mathrm{Y}$ & M & $\mathrm{N}$ & 31 & $\mathrm{~N}$ & M & $\mathrm{N}$ & 43 & $\mathrm{Y}$ & M & $\mathrm{N}$ \\
\hline 6 & $Y$ & $\mathrm{~F}$ & $\mathrm{~N}$ & 19 & $Y$ & M & $\mathrm{N}$ & 32 & $Y$ & M & $\mathrm{N}$ & 44 & $Y$ & $M$ & $\mathrm{~N}$ \\
\hline 7 & $\mathrm{Y}$ & $\mathrm{F}$ & $\mathrm{N}$ & 20 & $\mathrm{Y}$ & $M$ & $\mathrm{~N}$ & 33 & $\mathrm{Y}$ & M & $\mathrm{Y}$ & 45 & $\mathrm{Y}$ & $M$ & $\mathrm{~N}$ \\
\hline 8 & $\mathrm{Y}$ & $\mathrm{F}$ & $\mathrm{N}$ & 21 & $\mathrm{Y}$ & $M$ & $\mathrm{~N}$ & 34 & $\mathrm{Y}$ & M & $\mathrm{N}$ & 46 & $\mathrm{~N}$ & $M$ & $\mathrm{Y}$ \\
\hline 9 & $Y$ & $\mathrm{~F}$ & $\mathrm{~N}$ & 22 & $\mathrm{Y}$ & $\mathrm{M}$ & $\mathrm{N}$ & 35 & $Y$ & M & $Y$ & 47 & $\mathrm{Y}$ & $\mathrm{M}$ & $\mathrm{Y}$ \\
\hline 10 & $\mathrm{~N}$ & $\mathrm{~F}$ & $\mathrm{~N}$ & 23 & $\mathrm{~N}$ & M & $\mathrm{N}$ & 36 & $\mathrm{Y}$ & M & $\mathrm{N}$ & 48 & $\mathrm{Y}$ & $M$ & $\mathrm{~N}$ \\
\hline 11 & Y & $\mathrm{M}$ & $\mathrm{N}$ & 24 & $\mathrm{~N}$ & M & $\mathrm{N}$ & 37 & $\mathrm{Y}$ & M & $\mathrm{N}$ & 49 & $\mathrm{Y}$ & M & $\mathrm{N}$ \\
\hline 12 & $\mathrm{~N}$ & $\mathrm{~F}$ & $\mathrm{~N}$ & 25 & $\mathrm{Y}$ & M & $\mathrm{N}$ & 38 & $Y$ & M & $\mathrm{N}$ & 50 & $\mathrm{~N}$ & $\mathrm{M}$ & $\mathrm{N}$ \\
\hline 13 & $\mathrm{~N}$ & $\mathrm{~F}$ & $\mathrm{~N}$ & 26 & $\mathrm{Y}$ & $\mathrm{M}$ & $\mathrm{N}$ & & & & & & & & \\
\hline
\end{tabular}

Y: Yes, N: No, M: Male, F: Female

\subsection{Mathematical Model}

In this section, the mathematical model established for the selection, assignment, and scheduling of 50 staff for 3 tasks in a 31-day working period is included. In addition to the basic working constraints, the competence scores and trait data of the employees are included in the model. In addition, protection measures from the Covid-19 pandemic virus for personnel with chronic diseases are also reflected in the model.

\section{$\underline{\text { Parameters }}$}

$\begin{array}{lll}\mathrm{n} & : \text { The number of staff } & \mathrm{n}=50 \\ \mathrm{~m} & : \text { The number of days } & \mathrm{m}=31 \\ \mathrm{t} & : \text { The number of jobs } & \mathrm{t}=3 \\ \mathrm{z} & : \text { The number of staff data } & \mathrm{z}=7\end{array}$

i : Staff index $\quad i=1,2, \ldots, n$. 
j : Day index

$\mathrm{k} \quad$ : Job index

y : Staff competency and trait data index

$\mathrm{D}_{\mathrm{k}} \quad$ : Staff demand of $\mathrm{k}^{\text {th }}$ job

$\mathrm{F}_{\mathrm{k}}$ : set of non-assignment days of $\mathrm{k}^{\text {th }}$ job (Table 3)

$Y_{\text {iy }}:$ Information of $y^{\text {th }}$ data, $i^{\text {th }}$ staff (Table 4,5 ) $\mathrm{j}=1,2, \ldots, \mathrm{m}$.

("S", "M", "Mm", "Fm")

(“S”, “M”, "Me”, “ES”, “D”, “G”, “C”)

$\forall \mathrm{k}$

$\forall \mathrm{i}$

$\forall \mathrm{i}, \mathrm{y}$

$\underline{\text { Decisions variables }}$

$\mathrm{x}_{\mathrm{ijk}}=\left\{\begin{array}{lr}1, & \text { if staff } \mathrm{i} \text { is assigned to day } \mathrm{j} \text { on job } \mathrm{k} \\ 0, & \text { otherwise }\end{array}\right\}$

$\forall \mathrm{i}, \mathrm{j}, \mathrm{k}, \mathrm{y}$

In the model, it is aimed to make appointments in such a way that the competency points of the personnel are maximized. It was requested from the model to maximize the sums of points, not to maximize individual competencies for the tasks. Thus, it is aimed to put forward an effective work as a precaution to sudden job changes.

\section{Objective function of the model}

The objective function of the model is shown below. In the study, the staff has 4 competence points. An objective function has been created in which these competence scores are added to a single score and the obtained score is maximized.

$\operatorname{Maximize} \sum_{\mathrm{i}=1}^{50} \sum_{\mathrm{j}=1}^{31} \sum_{\mathrm{k}=1}^{3}\left(\mathrm{x}_{\mathrm{ijk}} *\left(Y_{i S}+Y_{i M}+Y_{i^{\prime \prime}} M e^{\prime \prime}+Y_{i^{\prime \prime} E S^{\prime \prime}}\right)\right)$

\section{Constraints of the model}

Ten hard constraints were used in the study. The constraints are shown below with their explanations.

Constraint 1: Any jobs must meet the staff demand on days when the staff are requested.

$$
\sum_{\mathrm{i}=1}^{50} \mathrm{x}_{\mathrm{ijk}}=D_{k} \quad \forall \mathrm{k} \& \forall \mathrm{j} \in \mathrm{m}-F_{k}
$$

Constraint 2: Assignment should not be made on days when the jobs do not request staff.

$$
\sum_{\mathrm{i}=1}^{57} \mathrm{x}_{\mathrm{ijk}}=0 \quad \forall \mathrm{j}, \mathrm{k} \in F_{k}
$$

Constraint 3: Any staff member can be assigned a maximum of 1 task on any given day.

$\sum_{\mathrm{k}=1}^{4} \mathrm{x}_{\mathrm{ijk}} \leq 1$

$$
\forall \mathrm{i}, \mathrm{j}
$$

Constraint 4: Test score constraint. There is a minimum score requirement for each job. Staff who cannot meet this score should not be assigned to the relevant task. The minimum scores in question are: 80 for $\mathrm{S}$, 70 for $\mathrm{M}$ and 60 for $\mathrm{Mm}$ and Fm. (Data from Table 4)

$\sum_{j=1}^{31} x_{i j S}=0$

$i \in Y_{i^{\prime \prime} E S^{\prime \prime}} \leq 80$

$\sum_{j=1}^{31} x_{i j M}=0$

$i \in Y_{i^{\prime \prime} E S^{\prime \prime}} \leq 70$ 
$\begin{array}{ll}\sum_{\mathrm{j}=1}^{31} \mathrm{x}_{\mathrm{ij} " \mathrm{Mm}}=0 & \mathrm{i} \in \mathrm{Y}_{i^{\prime \prime}} E S^{\prime \prime} \leq 60 \\ \sum_{\mathrm{j}=1}^{31} \mathrm{x}_{\mathrm{ij} " \mathrm{Fm}}=0 & \mathrm{i} \in \mathrm{Y}_{i^{\prime \prime} E S^{\prime \prime}} \leq 60\end{array}$

Constraint 5: Competence score constraint. Any staff with a task competency score ("S", "M", "Me") less than 7 should not be assigned to that task. (Data from Table 4)

$\sum_{\mathrm{j}=1}^{31} \mathrm{x}_{\mathrm{ijS}}=0$

$$
\mathrm{i} \in \mathrm{Y}_{i^{\prime \prime} S^{\prime \prime}} \leq 6
$$

$\sum_{\mathrm{j}=1}^{31} \mathrm{x}_{\mathrm{ijM}}=0$

$\mathrm{i} \in \mathrm{Y}_{i^{\prime \prime} M^{\prime \prime}} \leq 6$

$\sum_{\mathrm{j}=1}^{31} \mathrm{x}_{\mathrm{ij}} \mathrm{Mm}^{\mathrm{N}}=0$

$i \in Y_{i^{\prime \prime} M e^{n}} \leq 6$

$\sum_{\mathrm{j}=1}^{31} \mathrm{x}_{\mathrm{ij}} \mathrm{Fm}^{\prime}=0$

$i \in Y_{i^{\prime \prime} M e^{\prime \prime}} \leq 6$

Constraint 6: Male staff should not be assigned to the "Fm" job and female personnel to the "Mm" position. (Data from Table 5)

$\sum_{\mathbf{j}=1}^{31} \mathrm{X}_{\mathrm{ij}} \mathrm{Fm}^{\prime \prime}=0$

$$
\mathrm{i} \in \mathrm{Y}_{i C}=\text { "M" }
$$

$\sum_{\mathrm{j}=1}^{31} \mathrm{x}_{\mathrm{ij}} \mathrm{Mm}^{\prime}=0$

$$
\mathrm{i} \in \mathrm{Y}_{i C}=\text { "F" }
$$

Constraint 7: Staff without a driver license (D) should not be assigned to the "M" job. (Data from Table 5)

$\sum_{j=1}^{31} x_{i j M}=0$

$\mathrm{i} \in \mathrm{Y}_{i D}=$ "N"

Constraint 8: Assignments to $\mathrm{S}$ and $\mathrm{M}$ should not be accepted on weekends.

$\sum_{\mathrm{i}=1}^{50} \mathrm{x}_{\mathrm{ijS}}+\mathrm{x}_{\mathrm{ijM}}=0$

$\mathrm{j} \in 5,6,12,13,19,20,26,27$

Constraint 9: Staff with chronic diseases should not work within the scope of pandemic virus precautions.

$\sum_{\mathrm{j}=1}^{31} \sum_{\mathrm{k}=1}^{4} \mathrm{x}_{\mathrm{ijk}}=0$

$$
\mathrm{i} \in \mathrm{Y}_{i H}=\text { "Y" }
$$

Constraint 10: Those assigned to "Mm" and "Fm" jobs should not work more than 9 days within the scope of ergonomics measures

$\sum_{\mathrm{j}=21}^{31} \mathrm{X}_{\mathrm{ij} " \mathrm{Mm}} \leq \mathbf{9}$

$\sum_{\mathrm{j}=21}^{31} \mathrm{x}_{\mathrm{ij} " \mathrm{Fm} "} \leq 9$

$\forall \mathrm{i}$

Abbreviations in the constraints are from Table 5 (Y: Yes, N: No, M: Male, F: Female)

$\underline{\text { Solution of the model }}$

The model with 6200 decision variables and 2451 constraints was solved by IBM Ilog Cplex Optimization Studio program. The objective function value is $1,048,000$. The plan, in which pandemic measures were taken into account as well as staff competencies and various trait data, was successfully modeled and solved. Thanks to the competence scores, it is aimed to carry out an effective study. In addition, in the 
objective function, assignment and scheduling was made in case of a possible change of jobs by taking the total competence scores of the staff.

\section{RESULT AND DISCUSSION}

Model result is shown in Table 6.

Table 6. Solution of the model

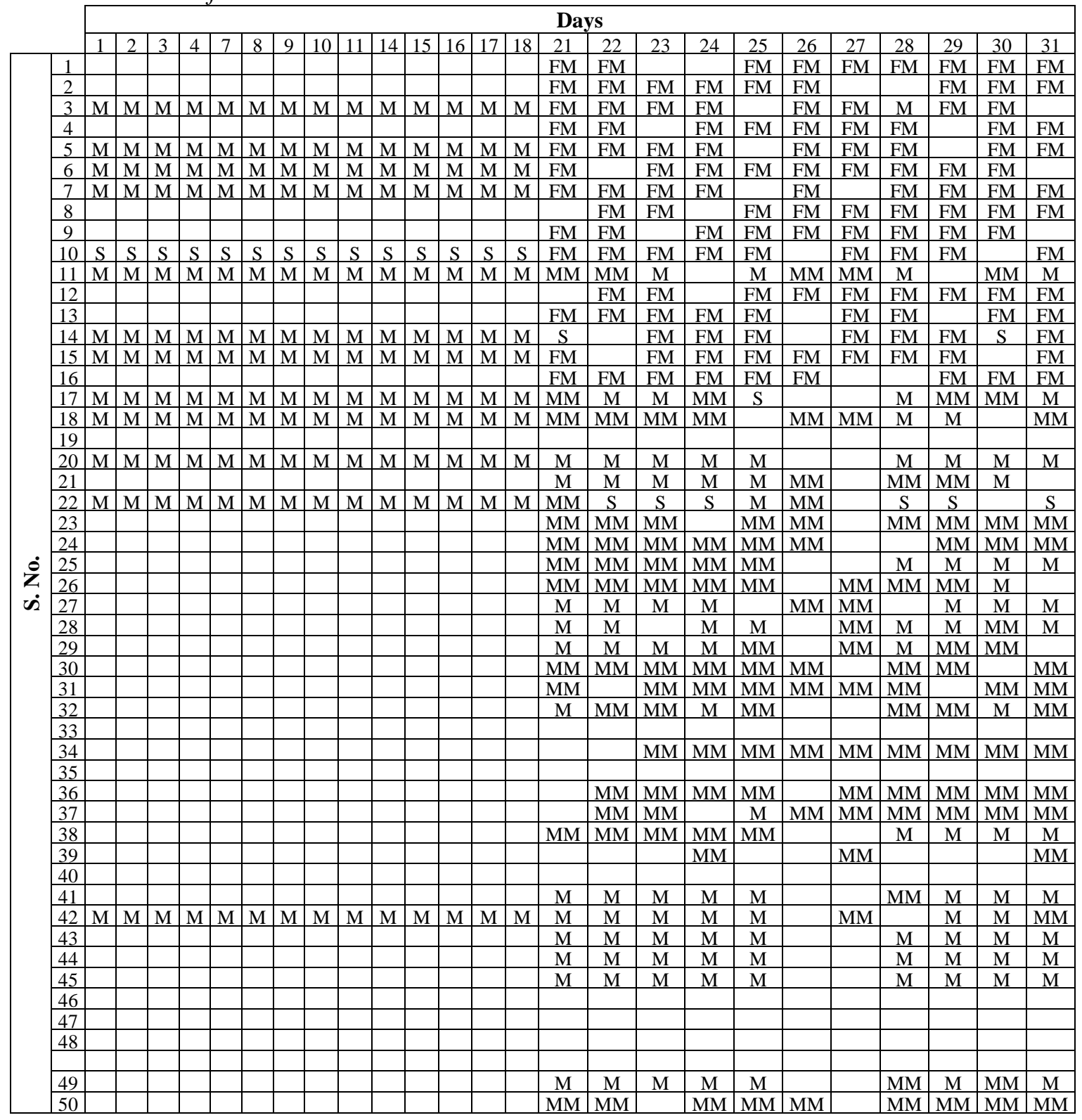

The study offers a solution to the problem of staff shortage caused by periodic changes in customer demand of a company operating in the food sector. The problem in question was solved by $0-1$ integer programming modeling method. 7 pieces of information of 50 staff, 4 of which are competency points and 3 of them trait data, have been included in the model and the most suitable number of staff has been determined. In this determination phase, the benefit from the staff has been maximized. Finding the ideal number of staff also helped to optimize the cost.

The tasks to be assigned by the staff to be employed on a periodic basis demand different requirements and characteristics due to their structures. Thanks to the staff data, the model has been observed in this case. Thus, the highest service quality was provided with the least cost. In addition, the appointment of competent 
staff in the field according to the task will prevent possible negativities as much as possible. In addition, the pandemic virus measures were also taken into consideration in the process of determining, assigning, and scheduling the staff in question, and the non-assignment of staff with hereditary illness was also included in the model, so that the whole system was carried out using scientific methods. Apart from these, due to the fact that some tasks are more tiring than physically, the staff assigned to this task are prevented from working in the same task for a long time and ergonomic working conditions are also taken into account.

Periodic staff needs is a problem faced by most businesses. All sectors where demand changes periodically are faced with staff hire work. This situation can cause difficulties for businesses and cause a decrease in the service quality of businesses. Considering the importance of employee compliance, the risks of temporary staff employment can be seen more clearly. Therefore, these processes should be carried out with the determination of competent staff who will fully meet the demands of the positions with staff shortage. In this case, it reveals the necessity to use scientific methods in the process. A problem-specific decision support system can be established in order to solve this problem as a standard in future studies.

Other future work suggestions for personnel scheduling problem can be listed as follows: The number of decision variables and constraints can be strategically reduced and grouped to make overtime constraints more practical in the field of implementation. With the changes to be made on the model, the model used in this study can be applied to other areas and the staff scheduling problems in other sectors can be solved.

\section{CONFLICTS OF INTEREST}

No conflict of interest was declared by the authors.

\section{REFERENCES}

[1] https://inkaparttime.com. Access date: 09.01.2021

[2] Asensio-Cuesta, S., Diego-Mas, J. A., Canós-Darós, L., and Andrés-Romano, C., "A Genetic Algorithm for The Design of Job Rotation Schedules Considering Ergonomic and Competence Criteria", The International Journal of Advanced Manufacturing Technology, 60(9): 1161-1174, (2012).

[3] Todovic, D., Makajic-Nikolic, D., Kostic-Stankovic, M., and Martic, M., "Police Officer Scheduling Using Goal Programming", Policing: An International Journal of Police Strategies and Management, 38: 295- 313, (2015).

[4] Ünal, F. M., Eren, T., "The Solution of Shift Scheduling Problem by Using Goal Programming", Academic Platform Journal of Engineering and Science, 4(1): 28-37, (2016).

[5] Ciritoğlu, C., Akgün, S., Varl1, E., and Eren, T., "Shift Scheduling Problem a Solution Suggestion for Safety Officers in University of Kırıkkale", International Journal of Engineering Research and Development, 9(2): 1-23, (2017).

[6] Varl1, E., Eren, T., "Nurse Scheduling Problems and An Application in Hospital", Academic Platform Journal of Engineering and Science, 5(1): 34-40, (2017).

[7] Varl1, E., Ergişi, B., and Eren, T., "Nurse Scheduling Problem with Special Constraints: Goal Programming Approach", Erciyes University Journal of Faculty of Economics and Administrative Sciences, 49(0): 189-206, (2017).

[8] Özder, E.H., Varl1, E., and Eren, T., "A Model Suggestion for Cleaning Staff Scheduling Problem with Goal Programming Approach”, The Black Sea Journal of Sciences, 7(2): 114-127, (2017). 
[9] Bedir, N., Eren, T., and Dizdar, E.N., "Ergonomic Staff Scheduling and An Application in the Retail Sector", Journal of Engineering Sciences and Design, 5(3): 657-674, (2017).

[10] Özcan, E. C., Varl1, E., and Eren, T., "Scheduling Shift Staff in Hydroelectric Power Plants with Goal Programming Approach", International Journal of Informatics Technologies, 10(4): 363370, (2017).

[11] Taş, M., Özlemiş, Ş. N., Hamurcu, M., and Eren, T., "Selection of Monorail Projects by Using Analytic Hierarchy Process and Goal Programming Combined Model”, Harran University Journal of Engineering, 2(2): 24-34, (2017).

[12] Gür, Ş., Hamurcu, M., and Eren, T., "Selecting of Monorail Projects with Analytic Hierarchy Process and 0-1 Goal Programming Methods in Ankara", Pamukkale University Journal of Engineering Sciences, 23(4): 437-443, (2017).

[13] Varlı, E., Alağaş, H., Eren, T., and Özder, E., "Goal Programming Solution of the Examiner Assignment Problem", Bilge International Journal of Science and Technology Research, 1(2): 105-118, (2017).

[14] De Bruecker, P., Beliën, J., Van den Bergh, J., and Demeulemeester, E., “A Three-Stage Mixed Integer Programming Approach for Optimizing the Skill Mix and Training Schedules for Aircraft Maintenance”, European Journal of Operational Research, 267(2): 439-452, (2018).

[15] Koçtepe, S., Bedir, N., Eren, T., and Gür, Ş., "Solution of Personnel Scheduling Problem for Organization Officers with 0-1 Integer Programming", Journal of Economy Business and Management, 2(1): 25-46, (2018).

[16] Yelek, A., Demirel, B., Alağaş, H. M., and Eren, T., "Part Time Staff Scheduling: Kırıkkale University Central Library Application”, Kırıkkale University Journal of Social Sciences, 8(2): 313-330, (2018).

[17] Koçtepe, S., Alağaş, H. M., Gür, Ş., and Eren, T., "Scheduling of the Organization Personnel in the Basketball Comparison with 0-1 Integer Programming Method", Başkent University Journal of Commercial Sciences, 3(2): 44-53, (2019).

[18] Danışan, T., Özcan, E., and Eren, T., "A Hybrid Model Proposal for Maintenance Scheduling in Hydropower Plants", Journal of the Faculty of Engineering and Architecture of Gazi University, 35(4): 1815-1828, (2020).

[19] Cürebal, A., Koçtepe, S., and Eren, T., "The Solution of the Organization Company Monthly Personnel Assignment and Scheduling Problem during the COVID-19 Pandemic: An Application", Journal of Turkish Operations Management, 4(2): 479-493, (2020).

[20] Cürebal, A., Koçtepe, S., and Eren, T., "The Staff Scheduling Problem at the Promotion Festival: An Application", Gazi Journal of Engineering Sciences, 6(3): 217-229, (2020).

[21] Heimerl, C., Kolisch, R., "Scheduling and Staffing Multiple Projects with A Multi-Skilled Workforce", OR Spectrum, 32(2): 343-368, (2010).

[22] Bender, M., Kalcsics, J., Nickel, S., and Pouls, M., "A Branch-And-Price Algorithm for the Scheduling of Customer Visits in the Context of Multi-Period Service Territory Design", European Journal of Operational Research, 269(1): 382-396, (2008). 